\title{
Protein Profiles and Identification of High Performance Liquid Chromatography Isolated Proteins of Cancer Cell Lines Using Matrix- assisted laser desorption/ionization Time-of-flight Mass Spectrometry
}

\author{
Bathsheba E. Chong', David M. Lubman ${ }^{1} *$, Allen Rosenspire ${ }^{2}$ and Fred Miller ${ }^{2}$ \\ ${ }^{1}$ Department of Chemistry, The University of Michigan, Ann Arbor, MI 48109-1055 \\ ${ }^{2}$ Department of Biological Sciences, Wayne State University, Detroit, MI 48202
}

SPONSOR REFEREE: A. Fox, School of Medicine, The University of South Carolina, Columbia, SC 29208, USA

\begin{abstract}
Matrix-assisted laser desorption/ionization time-of-flight mass spectrometry (MALDI-TOFMS) has been used to rapidly profile the protein content of human cell lysates from MCF-10 cell and variant lines. The method was used to study the protein profiles of these cells as they progressed from normal breast epithelium to fully malignant cells. Distinct differences in the protein profiles were observed with progression, and specific proteins associated with carcinogenesis (p53, c-myc, and c-erbB-2) were heavily expressed in these cells as detected by MALDI-TOFMS. These proteins were also isolated using non-porous reversed-phase high performance liquid chromatography (NP-RP-HPLC) and mass analyzed by MALDITOFMS to provide molecular weight information without interference from other proteins in the whole cell lysates, and to avoid suppression effects in mixtures of proteins detected by MALDI-TOFMS. In order to confirm the identity of these oncoproteins, the cell lysates were subjected to one-dimensional (1-D) gel separation and subsequently electroblotted onto a poly(vinylidene difluoride) (PVDF) membrane for further analysis. Trypsin and cyanogen bromide digestions were performed on these proteins eluted from excised PVDF bands which were then analyzed by MALDI-TOFMS. The identity of these proteins was confirmed by database matching procedures. (C) 1998 John Wiley \& Sons, Ltd.
\end{abstract}

Received 23 September 1998; Revised 7 October 1998; Accepted 8 October 1998

An important area in clinical oncology is the analysis of the expression of oncoproteins in the cell. A potentially powerful tool for rapidly screening for the presence of these oncoproteins in complex biological matrices such as cell lysates is matrix-assisted laser desorption/ionization time-of-flight mass spectrometry (MALDI-TOFMS). In previous work, MALDI-TOFMS has been used to rapidly differentiate and identify bacteria ${ }^{1-15}$ based on the analysis of the protein profiles of bacterial whole cell lysates employing a simple sonication ${ }^{1}$ or freeze-thaw method. ${ }^{10}$ Alternatively, several groups have demonstrated the use of MALDI to analyze intact bacterial cells and were able to identify the bacteria based on the observed protein spectral patterns. $^{2,3,13}$ In this work, relatively simple sample preparation methods were used which generally limited the observed MALDI-MS to water-soluble proteins under $20 \mathrm{kDa}$. In more recent work, much more extensive solubilizing procedures have been used such that large proteins up to several hundred kilodaltons $(\mathrm{kDa})$ have been observed from $E$. coli samples using MALDI-TOFMS of whole cell lysates. This $\operatorname{method}^{8}$ was used to monitor the

\footnotetext{
*Correspondence to: D. M. Lubman, Department of Chemistry, The University of Michigan, Ann Arbor, MI 48109-1055, USA.

Contract/grant sponsor: National Science Foundation; Contract/grant number: DEB 9120006.

Contract/grant sponsor: U.S. Army ERDEC; Contract/grant number:
} DAAD05-98-P-0796. induction or repression of expressed proteins in the mass range of 25 to $70 \mathrm{kDa}$ which resulted in response to Larabinose catabolism. In related work, an extensive solubilizing procedure has been used with MALDI-MS detection for the study of the protein patterns in mammalian cells and culture supernatants ${ }^{16}$ and, more recently, protein profiling of human cerebrospinal fluid has been performed. ${ }^{17}$

Oncogenes are mutated forms of normal genes that participate in the control of cellular proliferation and/or differentiation. Oncogenes implicated in breast carcinoma by experimental and clinical studies include c-erbB-2, $\mathrm{H}$ ras, c-myc, int-1, and int-2. ${ }^{18}$ Tumor suppressor genes are defined as genes that contribute to carcinogenesis by deletion, reduced expression, or inactivation. Strong evidence for the involvement of p53, a tumor suppressor gene in carcinogenesis, has come from studies of cell-cycle regulation. ${ }^{19}$ While the features of p53 are complex and reviewed extensively elsewhere, ${ }^{20,21}$ it should be noted that the loss of heterozygosity and/or mutation has been confirmed in a variety of tumor types, ${ }^{22}$ and especially in breast carcinoma. ${ }^{23-26}$ Oncoproteins, encoded by oncogenes and tumor suppressor genes, are crucial in the control of both normal and aberrant growth as they regulate a series of complex signal transduction pathways. When these pathways become deregulated, uncontrollable cell proliferation often results. The ability to rapidly detect and monitor 
abnormalities in oncoprotein expression may increase our understanding of the basic biological processes instrumental in tumor disease, and may also result in new methods for diagnosis and treatment of patients with cancer.

In this work, we describe a method for lysing of mammalian cells and for solubilizing the high molecular weight protein content of the cells. The sample preparation procedure developed for MALDI-TOFMS analysis allows for detection of proteins ( $>100 \mathrm{kDa}$ ) from human whole cell lysates. The human cells used represent the various stages of development in the MCF-10 cell line. This cell line was originated by spontaneous immortalization of breast epithelial cells obtained from a patient with fibrocystic disease. ${ }^{28}$ Using MALDI-TOFMS to analyze these MCF-10 cells may result in the identification of breast cancer genes involved in sporadic breast cancer. Because all lines constituting the full spectrum of progression from normal to malignant were derived from a single patient, irrelevant differences in gene expression should be minimal.

The goals of this work include using MALDI-TOFMS to study the expression of proteins in malignant cells not readily observed in normal cells or the higher levels of specific proteins present in malignant cells. MALDITOFMS analysis of the whole cell lysates of these MCF10 cells results in the detection of several oncoproteins that have been implicated in breast carcinoma which can be readily identified including $\mathrm{H}$-ras, c-myc, int $-2,{ }^{18}$ and p53. ${ }^{22-27}$ The known molecular weights of these oncoproteins from the Swiss-Protein Database were utilized as a guide to distinguish MALDI protein profiles originating from the malignant compared to the normal breast epithelium cell lysates. Fraction collection from non-porous reversed-phase high performance liquid chromatography (NP-RP-HPLC) of some of the protein peaks of the tumor whole cell lysate was also performed. The collected fractions were analyzed using MALDI-TOFMS to ascertain their molecular weights and to observe the expressed proteins without interference from suppression effects in the MALDI process. The protein profiles were also compared to the expressed bands of similar molecular weight observed in 1-D gels. The proteins on the 1-D gels were subsequently electroblotted onto poly(vinylidene difluoride) (PVDF) membranes, bands of interest were excised from the PVDF membrane and proteins were eluted off the bands. This was performed in order to identify the expressed bands using MALDI-TOFMS. Trypsin and cyanogen bromide digests were also performed on the eluted proteins and the resulting peptides from each protein were again examined by MALDI for protein identification and confirmation. The resulting peptides were compared to those found in the MS-Digest of the Protein Prospector Database. However, at this point no detailed sequencing has been performed on these proteins. Nevertheless, it is demonstrated that MALDI-TOFMS may indeed be a powerful analytical tool for applications involving identification and monitoring of oncoproteins as well as monitoring changes in oncogene expression in human breast carcinoma.

\section{EXPERIMENTAL}

\section{Chemicals}

The chemicals involved in this study were used without prior purification. Acetone (HPLC grade) was obtained from Fisher (Fair Lawn, NJ, USA). Acetonitrile, guanidine hydrochloride (gu-HCl), $\alpha$-cyano-4-hydroxycinnamic acid $(\alpha-\mathrm{CHCA})$ and phenylmethylsulfonyl fluoride (PMSF) were from Sigma (St. Louis, MO, USA), and Triton X-100 was from ICN (Aurora, OH, USA). The nitrocellulose (NC) used was Immobilon-NC Pure from Millipore (Bedford, MA, USA). Trifluoroacetic acid (TFA) and cyanogen bromide $(\mathrm{CNBr})$ were purchased from Aldrich (Milwaukee, WI, USA). Trypsin was acquired from Promega (Madison, WI, USA). Distilled and deionized water was obtained from a Mili-Q reagent grade purification system from Millipore (Bedford, MA, USA).

\section{Cell cultures}

The MCF-10 cell samples used in these experiments originated by spontaneous immortalization of breast epithelial cells from a fibrocystic patient. ${ }^{28}$ Fully malignant, metastatic variants, MCF-10 Cala, were also derived. ${ }^{29}$ Cells were maintained in a humidified $\mathrm{CO}_{2}$ incubator at $37^{\circ} \mathrm{C}$, and adherent cells harvested in log phase ( $\sim 75-80 \%$ confluence). In order to harvest the cells, the growth media was aspirated and the cells gently washed with PBS, prior to scraping with a rubber policeman. The cells were immediately frozen $\left(-80^{\circ} \mathrm{C}\right)$ upon removal from the tissue culture dishes.

\section{1-D SDS-PAGE and PVDF electroblotting}

Frozen cell pellets were directly solubilized in sodium dodecyl sulfate-polyacylamide gel electrophores (SDSPAGE) sample buffer under reducing conditions. Samples were boiled for $5 \mathrm{~min}$, and after cooling, separated on $10 \%$ acrylamide gels. After SDS-PAGE separation, proteins were electrophoretically transferred to a PVDF membrane (Micron Separations Inc., West Borough, MA, USA) in transfer buffer $(25 \mathrm{mM}$ Tris-HCl/192 mM glycine, $20 \%$ methanol, $\mathrm{pH} 8.2$ ) for $1.5 \mathrm{~h}$ at $13 \mathrm{~V} / \mathrm{cm}$. The proteins were visualized by staining with Coomassie blue after being transferred onto the PVDF membrane.

\section{Matrix, substrate and sample preparation}

$\alpha$-CHCA was the key matrix used in these experiments. The matrix was prepared as a saturated solution in a $4: 1$ ratio of acetone to Mili-Q water containing $0.5 \%$ TFA. Before applying the sample solution to the steel probe tip, $2 \mu \mathrm{L}$ of NC were applied to the tip and allowed to dry followed by 4 L of sample solution, which was also allowed to dry. Subsequently, $4 \mu \mathrm{L}$ of CHCA matrix solution were added to the probe tip and also allowed to dry.

Prior to lysis, the cell pellets were washed once with cold $10 \mathrm{mM}$ Tris- $\mathrm{HCl}$ buffer and $150 \mathrm{mM} \mathrm{NaCl}(\mathrm{pH}$ 7.5) via centrifugation for $3 \mathrm{~min}$ at $1000 \mathrm{~g}$. The cells were lysed by resuspension in $0.2 \mathrm{~mL}$ of $10 \mathrm{mM}$ Tris- $\mathrm{HCl}$ buffer $(\sim \mathrm{pH}$ 7.4), $6 \mathrm{M} \mathrm{gu}-\mathrm{HCl}$ and 10 to $20 \%$ Triton $\mathrm{X}-100$. This mixture was vortexed for at least $30 \mathrm{~s}$, and stored at $-20^{\circ} \mathrm{C}$ overnight. Subsequently, the lysate was fractionated by centrifugation in an Eppendorf centrifuge at $15000 \mathrm{~g}$ for 20 minutes. After the addition of $20 \mu \mathrm{L}$ of $1.0 \mathrm{mM}$ PMSF, the soluble portion was stored at $-20^{\circ} \mathrm{C}$ until MALDI analysis was performed.

Selected protein bands from the PVDF membrane were cut and placed in Eppendorf tubes. In order to remove the Coomassie blue stain from the bands, a de-staining solution consisting of $20 \%$ methanol, $10 \%$ acetic acid, and $70 \%$ 

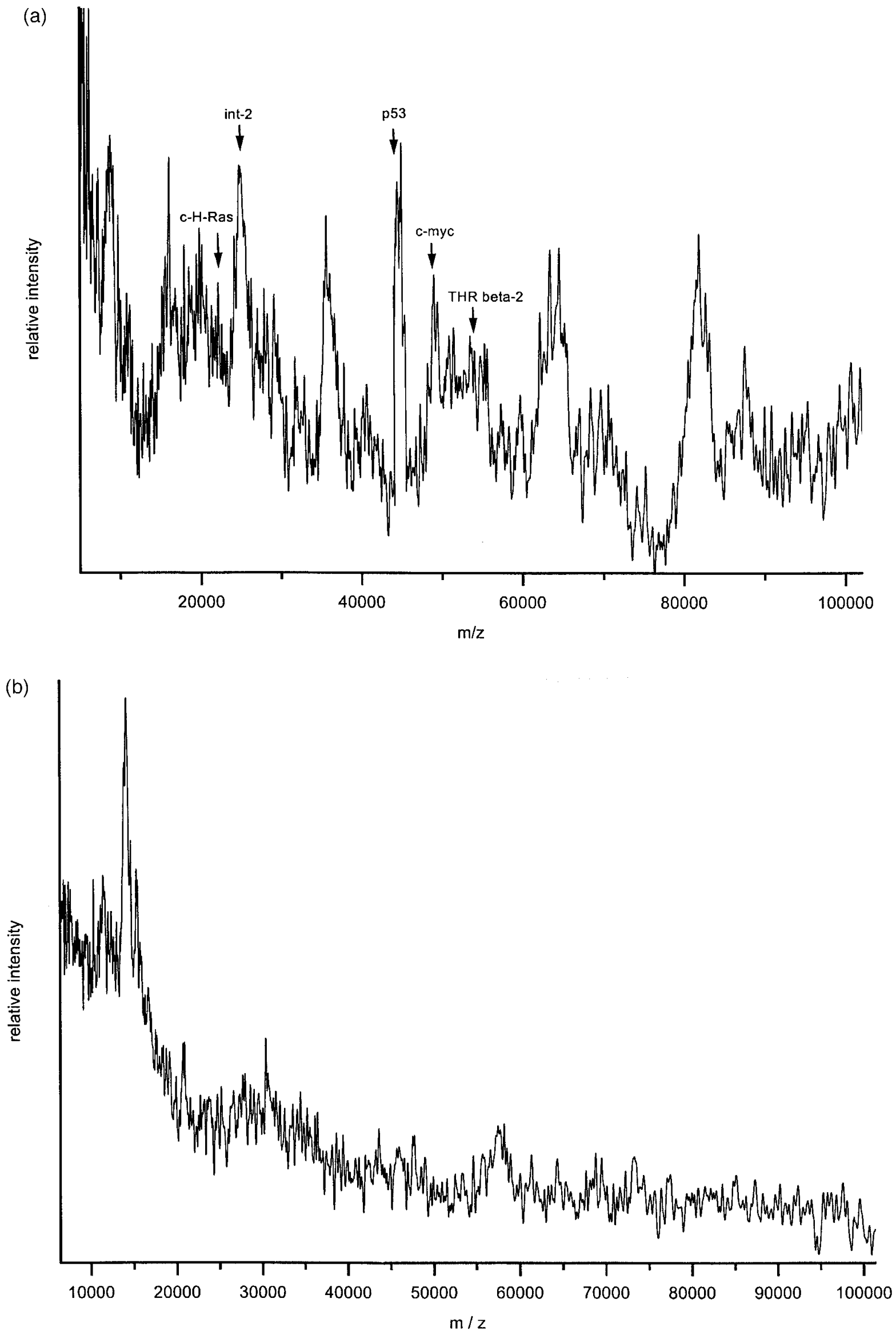

Figure 1. MALDI-TOF mass spectra of (a) malignant and (b) normal breast cell lysates from MCF-10 cell line. 


\begin{tabular}{|c|c|c|c|c|c|}
\hline $\begin{array}{l}\text { Accession } \\
\text { number }\end{array}$ & Protein name & Swiss-Protein & $\begin{array}{l}\text { 1-D Gel } \\
\text { (average) }\end{array}$ & $\begin{array}{c}\text { MALDI } \\
\text { (NP-RP-HPLC) }\end{array}$ & $\begin{array}{l}\text { Direct MALDI } \\
\quad \text { (average) }\end{array}$ \\
\hline P01112 & Transforming protein H-ras-1 (c-H-Ras) & 21298 & $\sim 21000$ & 21930 & 22210 \\
\hline P11487 & Int-2 proto-oncogene protein precursor (int-2) & 26886 & $\sim 27000$ & 26390 & 26310 \\
\hline P04637 & Nuclear Phosphoprotein (p53) & 43653 & $\sim 44000$ & 43680 & 44350 \\
\hline P01106 & MYC Proto-oncogene protein (c-myc) & 48804 & $\sim 49000$ & 49060 & 49040 \\
\hline P37243 & Thyroid hormone receptor beta- 2 (THR beta- 2$)^{a}$ & 54356 & $\sim 55000$ & 54460 & 54180 \\
\hline P04626 & ErbB-2 receptor protein-tyrosine kinase precursor (c-erbB-2) & 137911 & $\sim 140000$ & $141110^{b}$ & 141110 \\
\hline
\end{tabular}

Mili-Q water was employed. The tubes were gently shaken, and allowed to sit for 10-20 min. After decanting the solution, the bands were rinsed with Mili-Q water before being treated with the elution solution. The elution solution was prepared with $2 \%$ SDS, $10 \%$ Triton X-100, and $50 \mathrm{mM}$ Tris-HCl (pH 9-9.5). This was followed by centrifugation at $14000 \mathrm{~g}$ for $20 \mathrm{~min}$.

Trypsin digestion $(1 \mathrm{mg} / \mathrm{mL})$ was performed on the eluted proteins from the excised PVDF bands. An enzyme/ substrate ratio of 1:50 was used. These mixtures were incubated at $37^{\circ} \mathrm{C}$ for $24 \mathrm{hr}$. A CNBr digestion $(0.15 \mathrm{M}$ in $70 \%$ formic acid) was also performed on the eluted proteins at room temperature $\left(25^{\circ} \mathrm{C}\right)$ in the dark for $24 \mathrm{~h}$.

\section{NP-RP-HPLC analysis}

A Beckman (Fullerton, CA, USA) System Gold ${ }^{\circledR}$ HPLC was used for this work. It has a programmable solvent delivery module with a dual-pump (Model 127). This module includes a System Control Center display and keypad which permits control of the pump and external modules directly. The detector employed was a programmable detector module (Model 166) with a deuterium lamp. All separations were monitored at $214 \mathrm{~nm}$. The column was purchased from MICRA (Northbrook, IL, USA). It contained non-porous $\mathrm{C} 18$ packing material with a $1.5 \mu \mathrm{m}$ particle diameter. The dimension of the column was $4.6 \times 33 \mathrm{~mm}$ where the wide-bore column was necessary to collect an adequate amount of material and the short length allowed for rapid separations in minutes. The RPHPLC separation of proteins in the tumor cell lysate was performed via gradient elution of two solvents (solvent A: Mili-Q water with $0.1 \%$ TFA; solvent B: acetonitrile with $0.1 \%$ TFA) with a flow rate of $1 \mathrm{~mL} / \mathrm{min}$ where the temperature of the non-porous column was maintained at $60^{\circ} \mathrm{C}$ in a Timberline (Boulder, CO, USA) column heater. The gradient profile for solvent $\mathrm{B}$ was as follows: $0 \%, 1$ min; 0-20\%, 2 min; 20-60\%, 8 min; 60-100\%, 2 min; and $100-0 \%, 1 \mathrm{~min}$. The fractions collected were subsequently subjected to MALDI-TOF mass spectral analysis.

\section{MALDI-TOF mass spectral analysis}

The TOF mass spectrometer employed in these studies was a modified Wiley-McLaren design with a four-plate acceleration structure. ${ }^{30}$ It was capable of high voltage acceleration up to $\pm 20 \mathrm{kV}$ (R.M. Jordan Co., Grass Valley, CA, USA). The laser source used to produce MALDI was a Continuum Minilite $10 \mathrm{~Hz} \mathrm{Nd:YAG} \mathrm{laser} \mathrm{system} \mathrm{(Con-}$ tinuum, Santa Clara, CA, USA). The laser beam was focused onto the probe tip at a $45^{\circ}$ angle to the probe surface with a single 12.5 in f.l. quartz lens to spot a size of $\sim 0.2 \times 0.5 \mathrm{~mm}$. The resulting power density at this spot was estimated at $\sim 5 \times 10^{6}$ to $1 \times 10^{7} \mathrm{~W} / \mathrm{cm}^{2}$ at $355 \mathrm{~nm}$ radiation in these experiments. The detector was a triple microchannel plate (MCP) detector (R.M. Jordan Co.) which adapted a $\mathrm{CuBe}$ conversion dynode with postacceleration (PA) capability up to $\pm 12 \mathrm{kV}^{31}$ in front of the MCP. The total ion acceleration across the TOF device may thus be $>30 \mathrm{kV}$. The post-acceleration stage enhances the efficiency for detection of heavy species, but at the expense of resolution. The voltages were similar for all experiments, as follows: repeller at $+15 \mathrm{kV}$, extractor plate 1 at +10 to $+12 \mathrm{kV}$, extractor plate 2 at +3 to $+5 \mathrm{kV}$, extractor plate 3 was grounded, and PA at -10 to $-13 \mathrm{kV}$. The $1 \mathrm{~m}$ long TOF tube was pumped to a base pressure of $2 \times 10^{-7}$ Torr. Data was recorded using a LeCroy 9310 AM digital oscilloscope (LeCroy Corp., Chestnut Ridge, NY, USA) and was processed on a Gateway $586166 \mathrm{MHz}$ computer. Pulsed delay extraction (PDE) as described in previous work $^{32}$ was used for the trypsin and $\mathrm{CNBr}$ digest analyses. PDE was performed using a simple high voltage transistor switch constructed as described in previous work. ${ }^{32}$ The switch provided a $0-3 \mathrm{kV}$ voltage pulse with a 75 ns fall time.

Utilizing known molecular weights of the detected oncoproteins from the Swiss-Protein Database at http:// www.expasy.ch/sprot/ as a guide, protein peaks from the MALDI profiles of the tumor and normal whole cell lysates were identified. The whole cell lysates were then subjected to NP-RP-HPLC to isolate these proteins to further verify their identity by sizing the collected fractions with MALDI. Trypsin and $\mathrm{CNBr}$ digests were performed on the eluted proteins from the excised PVDF bands and the resulting peptides from each protein were again examined via MALDI for peptide identification and confirmation. The observed molecular weights of peptides were compared to those found in the MS-Digest of the Protein Prospector Database at http://prospector.ucsf.edu/.

\section{RESULTS AND DISCUSSION}

Figures 1(a) and (b) show the MALDI-TOF mass spectra of the malignant and normal whole cell lysates of the MCF-10 cell lines. The MALDI mass spectrum (Fig. 1(a)) of the malignant breast cell lysate is dominated by several protein peaks. In contrast, the MALDI mass spectrum of the cell lysate of a normal cell line shows very few protein peaks standing out above the background as shown in Fig. 1(b). The differences between the mass spectra may be explained by high expression of certain proteins in the malignant cell line but not in the normal cell line. The estimated molecular 

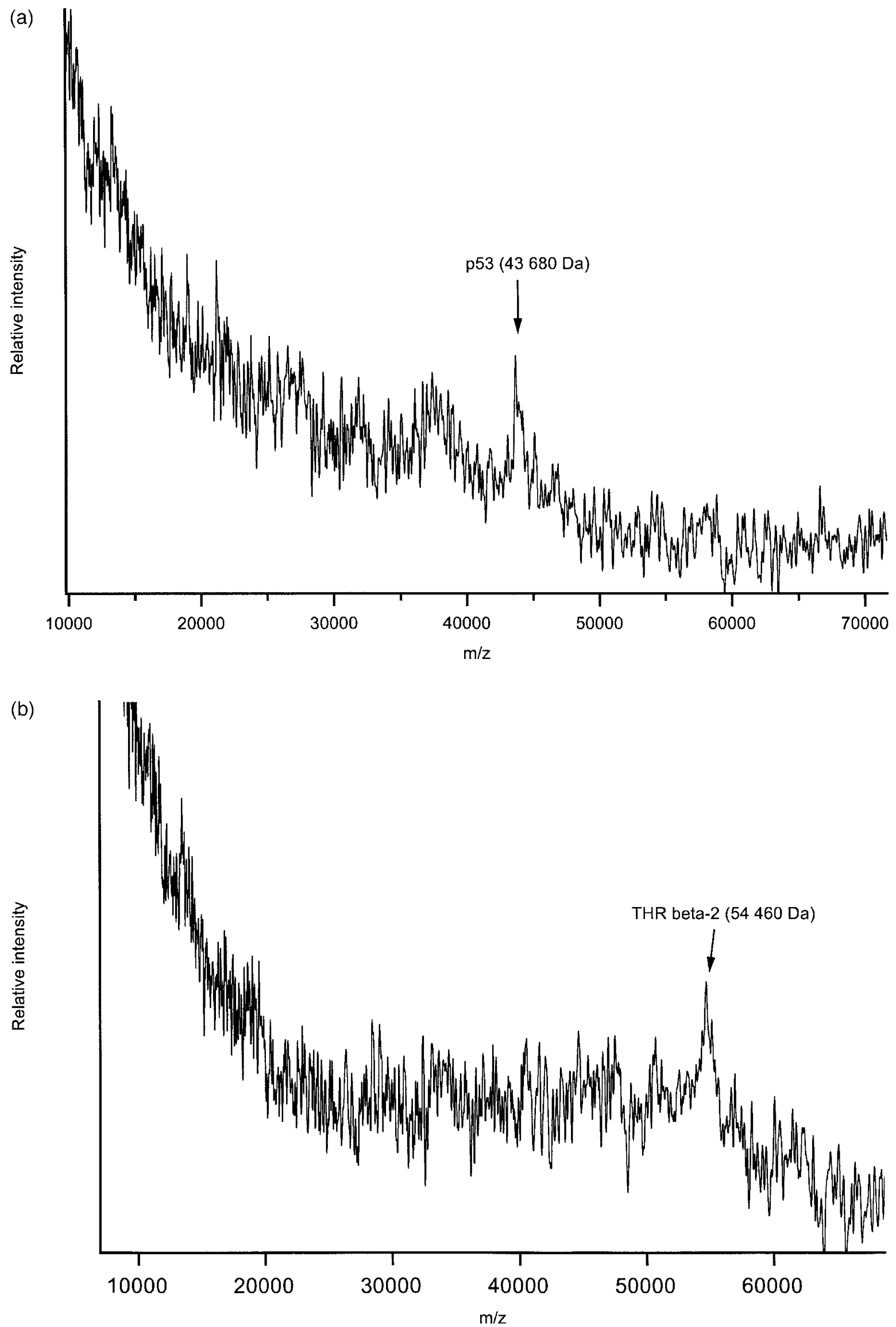

Figure 2. MALDI-TOF mass spectra of protein fractions collected from NP-RP-HPLC of (a) p53 and (b) THR beta-2. 


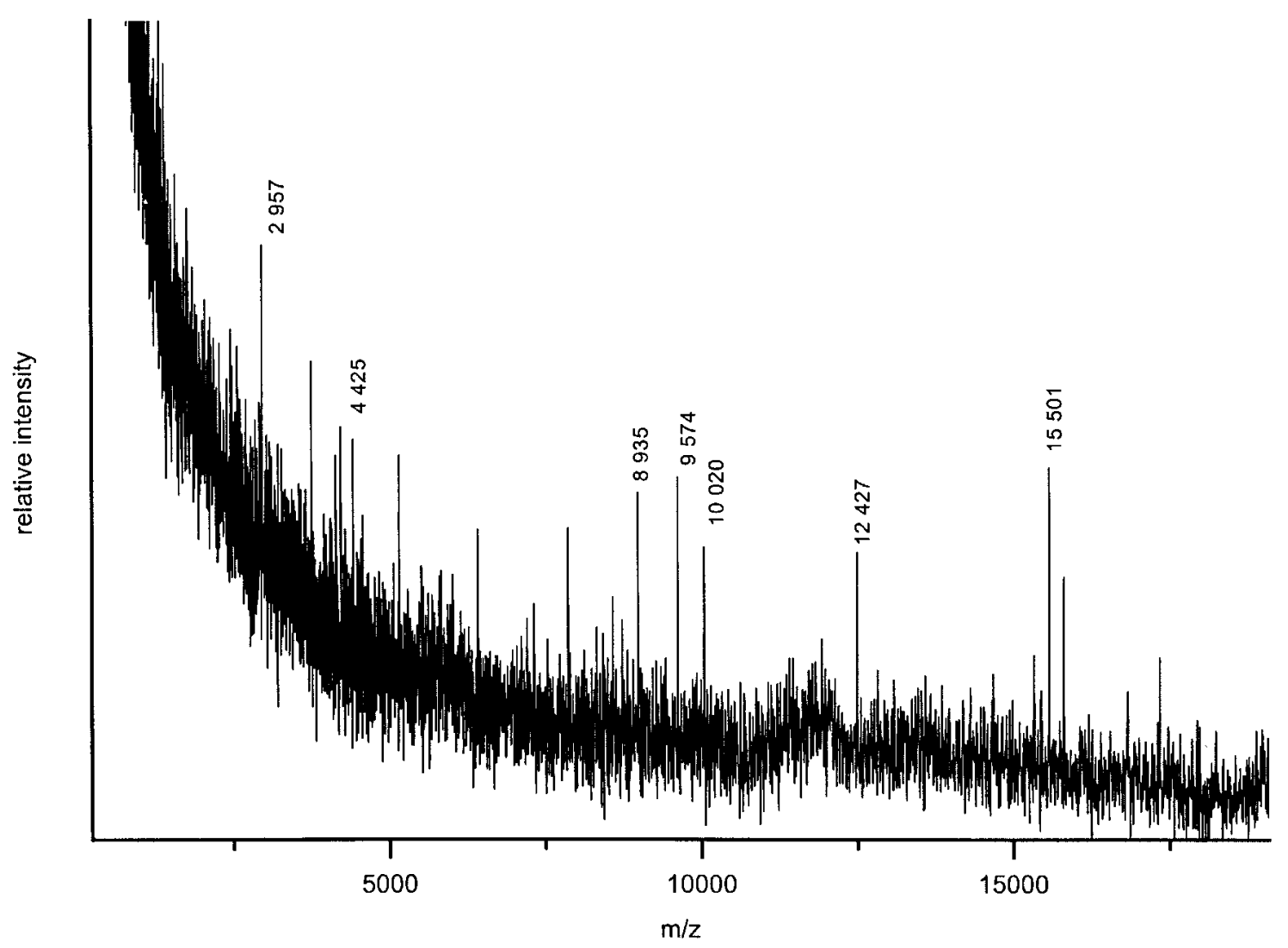

Figure 3. PDE-MALDI-TOF mass spectrum of CNBr digest of protein eluted from PVDF band. Probable candidate: p53.

weights corresponding to several of these peaks are tabulated in Table 1, with the possible identities of these proteins based on their molecular weights.

In order to more clearly distinguish and identify each of these major peaks, the whole cell lysates were separated by NP-RP-HPLC and the separated protein fractions collected. The fractions were then analyzed by MALDI-TOFMS to further verify the molecular weights of these key peaks. Figures 2(a) and (b) show the MALDI mass spectra of some of the protein fractions collected from the NP-RP-HPLC separation. In Fig. 2(a) the ion peak is detected around 43 $680 \mathrm{Da}$, which coincides with the p53 protein, while in Fig. 2(b) the protein fraction collected has a molecular weight of 54460 Da which would correspond to thyroid hormone receptor beta-2 (THR beta-2) protein. In addition, other fractions were collected and sized by MALDI where peaks were observed at 21930 and 26390 Da which probably correspond to c-H-ras and int-2 proteins, respectively. The molecular weights obtained by MALDI-TOFMS of NP-RPHPLC separated proteins are also tabulated in Table 1.

To confirm the results of Figs 1 and 2, and to identify the highly expressed tumor proteins, 1-D SDS-PAGE separations of these cell lysates (not shown) were performed which were subsequently electroblotted onto a PVDF membrane. Several proteins are definitely more heavily expressed than other proteins in the malignant lysate SDS-PAGE separation, and correspond in molecular weight to the expressed proteins observed on MALDI-TOFMS of the same lysate. Due to gel-to-gel variation observed in the 1-D gel separation, the molecular weights were averaged from several gels, as shown in Table 1. The molecular weights observed by direct MALDI-MS (averaged from several mass spectra), MALDI-MS of NP-RP-HPLC separated fractions and 1-D gel separations are fairly consistent and are similar to those of the Swiss Protein database for these cancer-related proteins. The differences in molecular weights may be due to various modifications and substitutions that may be present, but are not able to be identified without more extensive MS analysis or sequencing.

In order to further verify the identity of the overexpressed proteins, trypsin and $\mathrm{CNBr}$ digestions were performed on the proteins eluted from the excised PVDF bands of the whole cell lysates. A MALDI mass spectrum of a $\mathrm{CNBr}$ digest of one of the proteins is shown in Fig. 3. The resulting peaks detected in MALDI-TOFMS are tabulated in Table 2 and were comparable to the database $\mathrm{CNBr}$ digest of p53 protein. Similarly tryptic digestion was performed on this protein from the PVDF membrane to ascertain its identity. The peptides detected by MALDI-MS are compared to those from the database in Table 3. Both digestion methods and the molecular weights obtained appear to verify the identity of this protein as $\mathrm{p} 53$. CNBr and tryptic digests were also performed on the 49 and $55 \mathrm{kDa}$ proteins for analysis. The digestion products were compared to the database and appeared to confirm the identity of these proteins as c-myc and THR beta- 2 respectively (see Tables 4-7).

Although we did not actually sequence the proteins in this work, the MALDI analysis provided sufficient data regarding the identity of key expressed oncoproteins. Since this is a preliminary study, a continuation of this work will entail rigorous sequencing along with the investigation of geneprotein expression and variation in these cell lysates. For the current work, the detection of p53, c-erbB-2, c-myc and 
Table 2. CNBr digest of an overexpressed protein from the 1-D gel separation of MCF-10 Cala whole cell lysate (Fig. 3). Probable candidate: p53

MS-Digest: p53

Number of AA: 393

Sequence: Start-End

$41-66$

134-169

$1-40$

170-246

41-133

$161-243$

45-160

247-384

\begin{tabular}{cc} 
Database $\mathrm{MH}^{+}$(average) & $\mathrm{MALDI} \mathrm{MH}^{+}$ \\
2973.2 & 2957 \\
4200.9 & 4209 \\
4434.9 & 4425 \\
9087.2 & 8935 \\
9809.0 & 9574 \\
9961.1 & 10026 \\
12461.2 & 12427 \\
15707.8 & 15501 \\
\hline
\end{tabular}

Table 3. Trypsin digest of an overexpressed protein from the 1-D gel separation of MCF-10 Cala whole cell lysate. Probable candidate: $\mathbf{p 5 3}$

MS-Digest: p53

Number of AA: 393

Sequence: START - END

176-196

$1-24$

$133-158$

$66-110$

214-267

210-267

$1-65$

Database $\mathrm{MH}^{+}$(average)
2511.8
2688.9
3074.7
4506.1
6144.0
6678.6
7402.1

MALDI MH
2591
2678
3069
4339
5989
6683
7472

Table 4. CNBr digest of an overexpressed protein from the 1-D gel separation of MCF-10 Cala whole cell lysate. Probable candidate: THR beta-2

\begin{tabular}{lcc}
$\begin{array}{l}\text { MS-Digest: THR beta-2 } \\
\text { Number of AA: } 476\end{array}$ & \\
Sequence: Start-End & Database $\mathrm{MH}^{+}$(average) & MALDI $\mathrm{MH}^{+}$ \\
$446-476$ & 3686.4 & 3672 \\
$308-349$ & 5003.8 & 5054 \\
$395-445$ & 6245.2 & 6075 \\
$374-438$ & 7678.8 & 7762 \\
$190-307$ & 13386.3 & 12446 \\
$70-189$ & 14663.8 & 14724 \\
\hline
\end{tabular}

THR beta-2 in the tumor whole cell lysate (Fig. 1(a)) coincides with the expression of proteins on the PVDF membrane. It is generally believed that c-erbB-2 amplification/overexpression in breast cancer identifies a subset of patients with poor prognosis tumors. ${ }^{33}$ Even though the prognostic value of p53 immunohistochemical expression in breast cancer is still controversial, ${ }^{34}$ many reports have shown that p53 overexpression may be an indicator of poor prognosis in breast cancer. ${ }^{35,36} \mathrm{~A}$ recent study also suggests that p53 and c-erbB-2 oncoproteins could be considered as biomarkers of the biological aggressiveness of breast carcinoma, but their significance in the evaluation of the response to treatment and survival time seems to be limited. ${ }^{37}$ In other studies, c-myc and another oncoprotein (bcl-2) may play roles in the control of cellular and nuclear trafficking of p53 since they were detected mainly at the outer nuclear membrane in the cell and their levels and that of nuclear p53 are inversely correlated. ${ }^{38,39}$ Amplification and elevation of c-myc in breast carcinomas also appear to be an independent prognostic marker of overall survival. ${ }^{40} \mathrm{It}$
Table 5. CNBr digest of an overexpressed protein from the 1-D gel separation of MCF-10 Cala whole cell lysate. Probable candidate: $\mathrm{c}-\mathrm{myc}$

$\begin{array}{lcc}\text { MS-Digest: c-myc } & & \\ \text { Number of AA: } 439 & & \\ \text { Sequence: Start-End } & \text { Database } \mathrm{MH}^{+} \text {(average) } & \text { MALDI MH }^{+} \\ 1-134 & 15423.0 & 15224 \\ 135-439 & 34112.0 & 36228\end{array}$

Table 6. Trypsin digest of an overexpressed protein from the 1-D
gel separation of MCF-10 Cala whole cell lysate. Probable candidate: THR beta-2

\begin{tabular}{lcc}
$\begin{array}{l}\text { MS-Digest: THR beta-2 } \\
\text { Number of AA: 476 }\end{array}$ & \\
Sequence: Start-End & Database $\mathrm{MH}^{+}$(average) & MALDI MH ${ }^{+}$ \\
$119-128$ & 1223.4 & 1215 \\
$445-458$ & 1706.1 & 1698 \\
$149-165$ & 2068.4 & 2060 \\
$298-321$ & 2952.6 & 2973 \\
$305-331$ & 3415.3 & 3424 \\
$74-109$ & 4234.6 & 4245 \\
$217-255$ & 4455.9 & 4567 \\
$358-409$ & 5556.4 & 5579 \\
$354-406$ & 5628.4 & 5785 \\
$1-71$ & 8307.1 & 8176 \\
\hline
\end{tabular}

Table 7. Trypsin digest of an overexpressed protein from the 1-D gel separation of MCF-10 Cala whole cell lysate. Probable candidate: $\mathrm{c}-\mathrm{myc}$

$\begin{array}{lcc}\begin{array}{l}\text { MS-Digest: c-myc } \\ \text { Number of AA: 439 }\end{array} & \\ \text { Sequence: Start-End } & \text { Database } \mathrm{MH}^{+} \text {(average) } & \text { MALDI } \mathrm{MH}^{+} \\ 52-65 & 1582.9 & 1584 \\ 341-355 & 1752.9 & 1758 \\ 66-83 & 2012.3 & 2016 \\ 299-317 & 2262.5 & 2281 \\ 276-299 & 2469.8 & 2402 \\ 399-421 & 2621.0 & 2622 \\ 127-156 & 3344.9 & 3210 \\ 11-51 & 5123.4 & 5055 \\ 67-143 & 8344.3 & 8295 \\ 167-269 & 11041.7 & 10747 \\ \end{array}$

should be noted that c-myc-induced cellular transformation, as opposed to a number of other oncogenes, results from alternately high expression of a normal coding sequence rather than activation by a point mutation, as occurs with ras for example. Nonetheless, the full oncogenic potential of cmyc involves cooperation with other oncogenes such as ras. $^{41}$

The rapid screening and detection of oncoproteins in human cells remain important problems. There are many potential genetic abnormalities that may result in a normal breast cell transforming into a cancer cell. Thus, one might expect differences in protein expression in different tumors depending on the particular mechanism at work. Nevertheless, oncogene overexpression would be expected in breast tumor formation, and the oncogenes expressed should be related to the type of tumor and its mechanism for carcinogenesis. Moreover, in each case there may be mutated genes that express variants of oncoproteins so that methods for rapidly screening and identifying these proteins 
are sorely needed. Even more essential is the capability for monitoring subtle changes in protein expression as cells mutate from normal to pre-neoplastic to malignant phenotypes. It seems reasonable that changes in protein expression may be related to the cancer process.

In this initial work, MALDI-TOFMS of whole cell lysates or MALDI-TOFMS of protein fractions separated by NPRP-HPLC from whole cell lysates has been shown to be a powerful method for rapidly profiling expressed oncoproteins in tumor cells. This method may prove important for understanding mechanistic studies of gene-protein expression in human carcinomas. More significantly though, MALDI-TOFMS may prove to be an important analytical tool for detection and profiling of oncoproteins in different cell lysates as well as an important diagnostic tool for monitoring changes in oncogene expression in human breast carcinoma.

\section{Acknowledgements}

We gratefully acknowledge partial support of this work by the National Science Foundation Grant \#DEB 9120006 to the Center of Microbial Ecology at Michigan State University and by the U.S. Army ERDEC under contract \#DAAD05-98-P-0796.

\section{REFERENCES}

1. T. C. Cain, D. M. Lubman and W. J. Weber Jr., Rapid Commun. Mass Spectrom. 8, 1026 (1994).

2. R. D. Holland, J. G. Wilkes, F. Rafii, J. B. Sutherland, C. C. Persons, K. J. Voorhees and J. O. Lay, Rapid Commun. Mass Spectrom. 10, 1227 (1996).

3. T. Krishnamurthy and P. L. Ross, Rapid Commun. Mass Spectrom. 10, 1992 (1996).

4. T. Krishnamurthy, P. L. Ross and U. Rajamani, Rapid Commun. Mass Spectrom. 10, 883 (1996).

5. M. A. Claydon, S. N. Davey, V. Edwards-Jones and D. B. Gordon, Nature Biotechnology 14, 1584 (1996).

6. X. Liang, K. Zheng, M. G. Qian and D. M. Lubman, Rapid Commun. Mass Spectrom. 10, 1219 (1996).

7. M. Erhard, H. von Duhren and P. Jungblut, Nature Biotechnology 15, 901 (1997).

8. B. E. Chong, D. B. Wall, D. M. Lubman and S. J. Flynn, Rapid Commun. Mass Spectrom. 11, 1900 (1997).

9. R. J. Arnold and J. P. Reilly, Rapid Commun. Mass Spectrom. 12, 630 (1998)

10. J. A. Karty, S. Lato and J. P. Reilly, Rapid Commun. Mass Spectrom. 12, 625 (1998).

11. Z. Wang, L. Russon, L. Li, D. C. Roser and S. R. Long, Rapid Commun. Mass Spectrom. 12, 456 (1998).

12. K. J. Welham, M. A. Domin, D. Eoin Scannell, E. Cohen and D. S. Ashton, Rapid Commun. Mass Spectrom. 12, 176 (1998).

13. A. M. Haag, S. N. Taylor, K. H. Johnston and R. B. Cole, J. Mass Spectrom. 33, 750 (1998).

14. M. L. Easterling, C. M. Colangelo, R. A. Scott and I. J. Amster, Anal. Chem. 70, 2704 (1998).
15. P. Escoubas, B. J. Whiteley, C. P. Kristensen, M.-L. Celerier, G. Corzo and T. Nakajima, Rapid Commun. Mass Spectrom. 12, 1075 (1998).

16. J. H. M. van Adrichem, K. O. Bornsen, H. Conzelmann, M. A. S. Gass, H. Eppenberger, G. M. Kresbach, M. Ehrat and C. H. Leist, Anal. Chem. 70, 923 (1998).

17. A. Westman, C. L. Nilsson and R. Ekman, Rapid Commun. Mass Spectrom. 12, 1092 (1998).

18. W. J. Muller, Cancer Met. Rev. 10, 217 (1991).

19. W. E. Mercer, M. Amin, G. J. Sauve, E. Appella, S. J. Ullrich and J. W. Roman, Oncogene 5, 973 (1990).

20. D. P. Lane and S. Benchimol, Genes Dev. 4, 1 (1990).

21. A. J. Levine, J. Momand and C. A. Findlay, Nature 351, 453 (1991).

22. C. Caron de Fromental and T. Soussi, Genes Chrom. Cancer 3, 202 (1992).

23. P. Bertheau, S. M. Steinberg and M. J. Merino, Human Pathology 29, 323 (1998)

24. R. Molina, M. A. Segui, M. A. Climent, J. Bellmunt, J. Albanell, M. Fernandez, X. Filella, J. Jo, N. Gimenez, E. Iglesias, M. Miralles, C. Alonso, G. Piero, E. Perez-Picanol and A. M. Ballesta, Anticancer Res. 18, 507 (1998).

25. A. M. Thompson, T. J. Anderson, A. Condie, J. Prosser, U. Chetty, D. C. Carter, H. J. Evans and C. M. Steel, Int. J. Cancer 50, 528 (1992).

26. A. M. Thompson, C. M. Steel, U. Chetty, R. A. Hawkins, W. R. Miller, D. C. Carter, A. P. M. Forrest and H. J. Evans, Brit. J. Cancer 61, 74 (1990).

27. A. Harlozinska and J. K. Bar, Tumor Biol. 15, 223 (1994).

28. H. D. Soule, T. M. Maloney, S. R. Wolman, W. D. J. Peterson, R. Brenz, C. M. McGrath, J. Russo, R. J. Pauley, R. F. Jones and S. C. Brooks, Cancer Res. 50, 6075 (1990).

29. S. J. Santner, F. R. Miller, P. J. Dawson, L. Tait, H. D. Soule, J. Eliason and G. H. Heppner, Proc. Am. Assoc. Cancer. Res. 39, 202 (1998).

30. R. M. Whittal and L. Li, Anal. Chem. 67, 1950 (1995).

31. J. Bai, Y. H. Liu, T. C. Cain and D. M. Lubman, Anal. Chem. 66, 3423 (1994).

32. Y. D. Zhu, L. He, J. R. Srinivasan and D. M. Lubman, Rapid Commun. Mass Spectrom. 11, 987 (1997).

33. H. J. S. Dawkins, P. D. Robbins, K. L. Smith, M. Sama, J. M. Harvey, G. F. Sterrett and J. M. Papadimitriou, Pathol. Res. Pract. 189, 1233 (1993).

34. M. Barbareschi, Appl. Immnohistochem. 4, 106 (1996).

35. G. MacGrogan, F. Bonichon, I. de Mascarel, M. Trojani, M. Durand, A. Avril and J. M. Coindre, Breast Cancer Res. Treat 36, 71 (1995).

36. D. M. Barnes, E. A. Dublin, C. J. Fisher, D. A. Levison and R. R. Millis, Hum. Pathol. 24, 469 (1993).

37. M. Bebenek, J. K. Bar, A. Harlozinska and P. Sedlaczek, Anticancer Res. 18, 619 (1998).

38. J. J. Ryan, E. Prochownik, C. A. Gottlieb, I. J. Apel, R. Merino, G. Nunez and M. F. Clarke, Proc. Natl. Acad. Sci. USA 91, 5878 (1994).

39. S. Krajewski, S. Tanaka, S. Takayama, M. J. Schibler, W. Fenton and J. C. Reed, Cancer Res. 53, 4701 (1993).

40. E. M. J. J. Berns, J. A. Foekens, W. L. J. VanPutten, I. L. VanStaveren, H. Portengen, W. C. H. Dekoning and J. G. M. Klign, Cancer Res. 43, 13 (1992).

41. G. C. Prendergast, D. Lawe and E. B. Ziff, Cell 65, 395 (1991). 